ISSUE 4 (06) 2018

UDC: 656.025

DOI 10.26661/2522-1566/2018-4/06-08

\title{
CONTROLLING IN THE MANAGEMENT OF FINANCIAL AND ECONOMIC SECURITY OF ENTERPRISES
}

NADIIA SHMYHOL, Doctor of Economics, Professor, Head of the Department of Accounting and Taxation, Zaporizhzhia National University, Zaporizhzhia

VIACHESLAV DURNIN, Master of Accounting and Taxation

Department, Zaporizhzhia National University, Zaporizhzhia

YEVHEN OLEKSENKO, Master of Accounting and Taxation

Department, Zaporizhzhia National University, Zaporizhzhia
The relevance of the research topic is due to the need to justify the advantages of using controlling in the management of financial and economic security of enterprises in Ukraine.

The purpose of the article is to develop theoretical positions and methodological recommendations for improving the controlling system in the management of financial and economic security of enterprises.

The methodological basis of the research is comprehension of the totality of theories and scientific approaches to controlling, grounded in the works of national and foreign scientists. During the study, the following methods and approaches were used: methods of analysis and synthesis, abstract and concrete, historical method, factor analysis, structural and functional analysis, system approach.

Findings. It is proved that the complex structure of the enterprise controlling system must meet all needs, correspond to the goals and objectives of a particular enterprise and be adapted to its internal and external environment. At the same time, it should be unique and flexible, allowing for any changes that depend on the needs and capabilities of the organization.

It is also proved that in the complex index of financial firmness the following indicators were removed: coefficient of maneuverability of current assets, coefficient of assets mobility, index of fixed assets. In our opinion, these indicators are not so important to reflect the financial sustainability of the enterprise, since coefficient of maneuverability of current assets is directly related to the cash turnover ratio, and the coefficient of asset mobility is related to the current asset turnover.

Keywords: controlling, financial and economic security, complex index of financial firmness, controlling system of an enterprise.

\section{КОНТРОЛІНГ В УПРАВЛІННІ ФІНАНСОВО-ЕКОНОМІЧНОЮ БЕЗПЕКОЮ ПІДПРИЕМСТВ}

Актуальність теми дослідження зумовлена необхідністю обгрунтування переваг використання контролінгу в управлінні фінансово-економічною безпекою підприємств в Україні.

Метою статті $є$ розробка теоретичних положень і методичних рекомендацій по удосконаленню системи контролінгу в управлінні фінансово-економічною безпекою підприємств.

Методологічною основою дослідження $\epsilon$ осмислення сукупності теорій і наукових підходів до контролінгу, обгрунтованих у працях вітчизняних та зарубіжних учених.

\section{ШМИГОЛЬ НАДІЯ}

МИКОЛАЇВНА, д.е.н., професор, завідувач кафедри обліку та оподаткування ЗНУ, м.Запоріжжя

\section{ДУРНІН В'ЯЧЕСЛАВ}

АНАТОЛІЙОВИЧ, магістр кафедри обліку та оподаткування ЗНУ. м.Запоріжжя

\section{ОЛЕКСЕНКО ЄВГЕН} СВГЕНОВИЧ, магістр кафедри обліку та оподаткування ЗНУ, м.Запоріжжя 
ВИПУСК 4 (06) 2018

У ході дослідження використано такі методи й підходи: методи аналізу і синтезу, абстрактного та конкретного, історичний метод, факторний аналіз, структурно-функціональний аналіз, системний підхід. В роботі проведено аналіз досвіду побудови логістичних центрів в провідних країнах світу.

Доведено, що складна структура системи контролінгу підприємства повинна відповідати всім потребам, відповідати цілям і задачам конкретного підприємства і бути адаптованою до його внутрішньої і зовнішньої середах. Одночасно вона повинна бути єдиною і гнучкою, що дозволяє проводити будь-які ії зміни, що залежать від потреб і можливостей організації..

Доведено, що в комплексному показнику фінансової стійкості були видалені такі показники: коефіцієнт маневреності оборотних активів, коефіцієнт мобільності активів, індекс постійних активів. На нашу думку зазначені показники не є настільки важливим для відображення фінансової стійкості підприємства, оскільки коефіцієнт маневреності оборотних активів напряму пов'язаний із коефіцієнтом оборотності грошових коштів, а коефіцієнт мобільності активів пов'язаний із коефіцієнтом оборотності оборотних активів.

Ключові слова: контролінг, фінансово-економічна безпека, комплексний показник фінансової стійкості, системи контролінгу підприємства.

Problem statement. In conditions of a market economy, the actual task is to create a system of methods for diagnosing the states of safety (danger) of the enterprise, which allows, basing on the information received and properly processed, to calculate objective criteria, on the basis of which not only the state of danger can be recorded, but also the enterprises can be found on which worsening of financial standing is possible the future.

Therefore, we set ourselves the task to determine the place of research in the system of existing approaches, directions and methods of controlling and financial and economic analysis (diagnostics) to determine the critical states of economic entities, as well as their specifics and features.

The growing popularity of controlling can be accounted for new opportunities not only for financial management, but also for the management of the company as a whole. Enterprises that have created a controlling service have increased the efficiency of using all types of resources, significantly improved the quality of management decisions, and hence the financial and economic security of enterprises. However, it should be noted that the scheme of controlling, which operates abroad, cannot be fully implemented in our conditions.

\section{Analysis of recent research.}

When analyzing the views on the essence of controlling, it is revealed that the issues of accounting and analytical support for the economic security of enterprises were investigated by many scholars, namely R. Mann [1], E. Mayer [2], N. Gladkih [3], V. Lagutin [4], A. Kozub [5], I. Blank [6], P. Horvath [7], N. Losbichler [8], and others.

Insufficient development of theoretical and methodological provisions of controlling, as well as the scientific-theoretical and practical significance of these problems, led to the choice of the topic.

\section{Formation of the purpose of the article.}

The purpose of the article is to develop theoretical provisions and methodological recommendations for improving the controlling system in the management of financial and economic security of enterprises.

\section{Presentation of the main results.}

Modern controlling is provided by very diverse tools. The views of the vast majority of researchers in the area of controlling converge on the issue of maintaining controlling instruments and their compliance with the tasks, as well as their integration with methods of financial and economic security management of enterprises (Table 1). 
ISSUE 4 (06) 2018

Table 1

Characteristics of general controlling tools

\begin{tabular}{|c|c|c|}
\hline Integrated tasks & Tools & Characteristic \\
\hline $\begin{array}{l}\text { Operative collection of } \\
\text { information, presentation } \\
\text { of information, adaptive } \\
\text { planning }\end{array}$ & $\begin{array}{l}\text { Management } \\
\text { accounting tools }\end{array}$ & $\begin{array}{l}\text { Collection, registration and generalization of all } \\
\text { information for } \\
\text { decisions. Coverage of all business parties }\end{array}$ \\
\hline $\begin{array}{l}\text { Planning of functional } \\
\text { areas of activity }\end{array}$ & $\mathrm{Bud}$ & $\begin{array}{l}\text { The budget is a result of operational planning, } \\
\text { expressed in economic indicators. Serves to manage } \\
\text { costs, revenues and liquidity. Budgeting is a formal } \\
\text { planning process }\end{array}$ \\
\hline Analysis, control & $\begin{array}{l}\text { Analysis of deviations; } \\
\text { analysis of costs and } \\
\text { results }\end{array}$ & $\begin{array}{l}\text { The use of the main types of economic analysis - } \\
\text { factor analysis, cost analysis, comparative analysis }\end{array}$ \\
\hline $\begin{array}{l}\text { Project planning, product } \\
\text { planning }\end{array}$ & \begin{tabular}{lr|} 
Network & planning; \\
investment \\
calculations; \\
calculations
\end{tabular} & $\begin{array}{l}\text { Network planning is used for complex objects and } \\
\text { projects. Calculations and estimates are used to } \\
\text { determine costs }\end{array}$ \\
\hline Program planning & $\begin{array}{lr}\text { Break-even } & \text { point } \\
\text { analysis; } & \text { portfolio } \\
\text { analysis; } & \text { performance } \\
\text { calculations; } & \end{array}$ & $\begin{array}{l}\text { Allow you to choose the optimal version of production } \\
\text { in the prevailing conditions, the most profitable } \\
\text { options for production, to calculate the impact of risk } \\
\text { factors and choose the best investment option. }\end{array}$ \\
\hline
\end{tabular}

Most authors who are researching controlling problems agree that controlling tools can be divided into strategic controlling tools and operational controlling tools. Such a conclusion obviously follows from the intended use of these types of controlling.

Operational and strategic controlling are in constant interaction. Operational planning depends on the strategic one. Conversely, operational decisions provide important impulses for the strategic stabilization of the enterprise.

The main difference between strategic controlling and operative is that the strategic controlling is focused on the tendencies of the future, while operational one is based on the "past". It defines the fundamental differences between strategic and operational controlling in goal setting, the domination of functional zones, objects of planning and control, tools.

But for each specific organization, the system of controlling will be its own, due to the peculiarities and specifics of each organization, it is impossible to implement a ready-made model of the controlling system.

Table 2 lists more than 60 instruments that can be used for controlling arrangements at Ukrainian enterprises.

Most of them relate to well-known methods of management arrangements, characteristics of which can be found in many Ukrainian and foreign publications.

In the market system activities, an objective assessment of the financial security level of an enterprise becomes of special importance. A large number of in-depth analysis and rapid analysis techniques based on the use of absolute and relative indicators have been developed for its determination. Such techniques allow you to identify problem areas in the enterprise and investigate the reasons that led to them, but do not provide an opportunity to make substantiated conclusions about its level of financial security in general. 
ВИПУСК 4 (06) 2018

\section{Tools of controlling}

\begin{tabular}{|l|l|}
\hline No. & \multicolumn{1}{|c|}{ Tool } \\
\hline 1 & Make or Bay analysis \\
\hline 2. & Analysis of bottlenecks \\
\hline 3. & ABC analysis \\
\hline 4 & Break-even point analysis \\
\hline 5 & Analysis of the product life cycle \\
\hline 6 & $\begin{array}{l}\text { Analysis of enterprise } \\
\text { accounting of investments) }\end{array}$ \\
\hline 7 & Economic analysis \\
\hline 8 & Competition analysis \\
\hline 9 & Market vulnerability analysis \\
\hline 10 & Margin Analysis \\
\hline 11 & Analysis of weak and strong points \\
\hline 12 & Opportunity analysis \\
\hline 13 & Analysis of sales volumes \\
\hline 14 & Analysis of deviations \\
\hline 15 & Portfolio analysis \\
\hline 16 & Potential analysis \\
\hline 17 & Analysis of the threshold of profitability \\
\hline 18 & Analysis of discounts \\
\hline 19 & Regression analysis \\
\hline 20 & Risk analysis \\
\hline 21 & Network analysis \\
\hline 22 & SWOT analysis \\
\hline 23 & Time series analysis \\
\hline 24 & Cost analysis \\
\hline 25 & Analysis of the order size \\
\hline 26 & XYZ analysis \\
\hline 27 & Non-cost analysis \\
\hline 28 & Benchmarking \\
\hline 29 & Strategic balance \\
\hline 30 & Budgeting \\
\hline 31 & Brainstorming \\
\hline 32 & CIM \\
\hline 33 & Cause and effect diagram \\
\hline 34 & Decision tree \\
\hline 35 & Just in time \\
\hline 36 & Gemba \\
\hline 37 & Kanban \\
\hline 38 & Kaizen \\
\hline 39 & Short-term record of results \\
\hline 40 & Experience curve \\
\hline 41 & Lean Management \\
\hline 42 & Delphi method \\
\hline 43 & The method of moving averages \\
\hline 44 & Methods of stock optimization \\
\hline & Ajoutee) \\
\hline & Spot models (scoring) \\
\hline
\end{tabular}

Table 2

\begin{tabular}{|l|l|}
\hline 47 & Optimization of sales \\
\hline 48 & Optimization of order size \\
\hline 49 & $\begin{array}{l}\text { Goal planning (multi-purpose } \\
\text { programming) }\end{array}$ \\
\hline 50 & Mathematical programming \\
\hline 51 & $\begin{array}{l}\text { Cost accounting (planned, actual, } \\
\text { permanent, variables, etc.) }\end{array}$ \\
\hline 52 & Probability theory \\
\hline 53 & Mathematical statistics \\
\hline 54 & Reengineering of an existing system \\
\hline 55 & Timely warning systems \\
\hline 56 & Target Costing \\
\hline 57 & The method of "scripts" \\
\hline 58 & Time Based Management \\
\hline 59 & Gantt chart \\
\hline 60 & Total Quality Management \\
\hline 61 & Activity Based Management \\
\hline
\end{tabular}

The analysis of scientific publications and practices of domestic enterprises on the analysis of financial security makes it possible to state that at present, there is no sufficiently effective method for assessing the level of financial security of an enterprise. At the same time, the results of the development of new techniques by foreign researchers can not be used by domestic enterprises, which is conditioned by the inability of developed models to provide an adequate assessment of the safety of those enterprises that operate in conditions that are different from the conditions for which model parameters were determined. Therefore, it is quite logical to focus on contemporary national research in the field of financial security analysis and controlling in order to find new approaches to assessing the level of financial security of an enterprise that would take into account the peculiarities of the functioning of Ukrainian enterprises.

In other words, when using foreign methods of assessing and controlling the level of financial security in Ukraine, one can face a sufficiently large number of problems, which is why Ukrainian scientists have a task to improve the methods and adapt them to national conditions of management.

Let us consider possible directions of controlling methods perfection for evaluation of the financial security state of an enterprise. In order to obtain an adequate assessment of the level of financial security of the enterprise, it is 
ISSUE 4 (06) 2018

advisable to compare the financial indicators characterizing the activity of the enterprise, not with the normative values that are developed for foreign economic conditions, but with:

- average values of similar indicators, calculated for the aggregate of enterprises in each industry, which produce the bulk of its products;

- values of the indicators recommended in the works of Ukrainian researchers, which meet the requirements of safe functioning;

- indicators of the activities of the best enterprises, etc.

This comparison shows whether the value of the relevant indicator for one or another enterprise is above the average Ukrainian level, or lower than it; the hitting of certain indicator values into certain ranges is estimated, as recommended by Ukrainian analysts.

In connection with the foregoing, we consider it necessary to use the values of the coefficients calculated for 60 enterprises in 6

different types of the sphere of material production of Ukraine.

This measure will make the assessment of the level of financial security more precise, and that reflects the real conditions of functioning of Ukrainian enterprises in the sphere of material production.

In addition, we consider it necessary to improve the methodology for assessing the financial security level of an enterprise in the sphere of material production by selecting such a list of indicators-components of the integrated assessment that would best characterize the key areas of its activities.

As a basis for improvement, we will take the method by Krakos Yu.B. and Razgon R.O. For clarity of the proposed changes, we submit information in the form of a table (Table 3). In the group of solvency indicators, the coefficient of maneuverability of current assets was attributed to a group of indicators of financial firmness and replaced by the coefficient of loss of solvency in the complex index of solvency assessment.

Table 3

Forecasted methodology for assessing the financial security level of an enterprise in comparison with the method by Krakos Yu.B. and Razgon R.O.

\begin{tabular}{|c|c|}
\hline Methods by Krakos Yu.B. and Razgon R. O. & Proposed methods \\
\hline 1 & 2 \\
\hline $\begin{array}{l}\text { 1. Complex index of management assessment: } \\
\text { - profitability of assets; } \\
\text { - profitability of own capital; } \\
\text { - total return on sales by gross profit; } \\
\text { - profitability of products. }\end{array}$ & $\begin{array}{l}\text { 1. Complex index of enterprise profitability } \\
\text { assessment: } \\
\text { - profitability of assets; } \\
\text { - profitability of own capital; } \\
\text { - total sales profitability; } \\
\text { - profitability of products. }\end{array}$ \\
\hline $\begin{array}{l}\text { 2. Complex index of solvency assessment and financial } \\
\text { firmness: } \\
\text { - coefficient of current liquidity; } \\
\text { - coefficient of absolute liquidity; } \\
\text { - ratio of payables and receivables; } \\
\text { - coefficient of maintenance of own working capital; } \\
\text { - coefficient of maneuverability of own capital. }\end{array}$ & $\begin{array}{l}\text { 2. Complex index of solvency assessment of the } \\
\text { enterprise: } \\
\text { - coefficient of current liquidity; } \\
\text { - coefficient of absolute liquidity; } \\
\text { - ratio of payables and receivables; } \\
\text { - coefficient of maintenance of own working capital; } \\
\text { - coefficient of loss of solvency. }\end{array}$ \\
\hline $\begin{array}{l}\text { 3. Complex index of business activity: } \\
\text { - turnover of assets; } \\
\text { - turnover of fixed assets; } \\
\text { - turnover of current assets; } \\
\text { - turnover of money; } \\
\text { - turnover of own capital. }\end{array}$ & $\begin{array}{l}\text { 3. Complex index of business activity: } \\
\text { - turnover of assets; } \\
\text { - turnover of fixed assets; } \\
\text { - turnover of current assets; } \\
\text { - turnover of money; } \\
\text { - turnover of own capital. }\end{array}$ \\
\hline
\end{tabular}


Table 3 Continuation

\author{
4. Complex index of market stability: \\ - coefficient of autonomy; \\ - coefficient of financial risk; \\ - coefficient of maneuverability of current assets; \\ - coefficient of assets mobility; \\ - index of fixed assets.
}

Such a change is due to the fact that these indicators give an idea of the degree to which the theoretical ability of the business entity to fulfill its obligations in case of occurrence of certain negative events, that is it gives a general description of its protective financial reserves. What, in our opinion, is very important in the method of assessing the level of financial security of an enterprise.

In the complex index of financial firmness, the following indicators were removed: coefficient of maneuverability of current assets, coefficient of assets mobility, the index of fixed assets. In our opinion, these indicators are not so important to reflect the financial firmness of an enterprise, since the coefficient of maneuverability of current assets is directly related to the cash turnover ratio, and the coefficient of assets mobility is related to the current asset turnover. One of the basic principles for building an effective method for assessing the level of financial security is as follows: "... individual indicators, selected for inclusion in the integral assessment, should not duplicate one another, since this duplication not only complicates the economic substantiation of the results but also can distort them ...". Moreover, these indicators would be more appropriate to attribute to the indicators of assessment of business activity of an enterprise.

As for the complex indicator of investment attractiveness, in our opinion, this group of indicators is not essential for assessing the level of financial security of an enterprise. The net revenue ratio reflects the proportion of net income in gross income that does not provide any information for potential investors, since the difference between gross income and net income is tax payments (VAT, duty, excise, etc.). Thus, this indicator can provide information only on the level of indirect
4. Complex index of financial firmness:

- coefficient of autonomy;

- coefficient of financial risk;

- coefficient of maneuverability of own capital;

- coefficient of financial firmness. taxation in the country. For a potential investor, the profitability indicators, that have already been taken into account in the proposed methodology, are more important. As for the net profit per share, it loses its informative value in our country. This is because today too few Ukrainian business entities pay due attention to their shareholders and most companies do not pay dividends at all. Therefore, the use of this indicator in the method of assessing the level of financial security is not feasible.

Instead of the complex index of investment attractiveness, we suggest using a complex index of the company's property status. One of the most problematic indicators of assessing the property situation in Ukraine is the coefficient of depreciation of fixed assets. That is why it is very important for assessing the level of financial security of an enterprise. In addition, it is necessary to include in the methodology the coefficient of renewal of fixed assets, which characterizes the policy of property management of an enterprise. In order to specify these indicators, it is necessary to apply the coefficient of return on fixed assets, since the effectiveness of their use should be evaluated and analyzed when analyzing the state of financial security of an enterprise. In our opinion, the proposed methodology will provide a more accurate and profound assessment of the state of financial security of an enterprise by modern methods of controlling.

Conclusion. The complex structure of the enterprise controlling system must meet all needs, meet the goals and objectives of the particular enterprise and be adapted to its internal and external environment. At the same time, it should be unique and flexible, allowing for any changes that depend on the needs and capabilities of the organization. Each particular organization will have its own the controlling 
ISSUE 4 (06) 2018

system, due to the peculiarities and specifics of each industrial organization, it is impossible to introduce a ready-made model of the controlling system. This is due to its strategy, which is implemented through a well-established organization of internal processes and the formation of an optimal organizational structure, which includes a system of controlling. Any transformations in the strategy caused by the market situation determine the need for the reorganization of internal business processes and structures, which leads to the need to tune the current system of controlling. Changes may also be caused by the introduction of new solutions in the field of theory and practice of controlling. As already mentioned, controlling is an integral part of the management of financial and economic security of enterprises. Controlling system is necessary to maintain competitiveness, which makes any modern enterprise to improve systems and procedures of its management.

\section{REFERENCES:}

1. Mann R., Mayer E. Controlling for beginners / Ed. by V.B. Ivashkevich; transl. from German by Yu.G. Zhukova. Moscow: Finance and Statistics, 1995. p. 304.

2. Mayer E. Controlling as a system of thinking and management: transl. from German by /ed. by S.A. Nykolaeva. Moscow: Finance and Statistics, 1993. p. 92.

3. Gladkih, N.I. (2000), "Controlling mechanism in the enterprise management system", Abstract of the Doctor thesis,
Economics, organization and management of enterprises, Institute of Economics and Industry of NAS of Ukraine, Donetsk, Ukraine

4. Lagutin, V.D. Market, competition and value in the conditions of modern economic development / V.D. Lagutin // Formation of market economy [Electronic resource]: collection of sciences works. - Special edition. Methodological Problems of Modern Political Economy / Ministry of Education and Science, Youth and Sport of Ukraine, Kyiv National Economic University named after V. Hetman; O.O. Belyaev - K .: KNEU, 2011. - pp. 114 121.

5. Kozub O.V. Formation of a management system of industrial enterprises based on controlling [Text]: thesis ... Candidate of economic sciences: 08.00.04: defended 18.09.2009 / Kozub Olena Viktorivna; Classical private university. Zaporizhzhie, 2009. p. 202.

6. Blank, I.O. Financial strategy of the enterprise: monograph / under general scientific editorship by I.O. Blank, G.V. Sitnik, O.V. Korolova-Kazanskaya, I.G. Hanechko K. Kyiv national university of trade and economics, 2009. p.147.

7. Horvath \& Partners Controlling in trading companies, insurance companies, banks. URL: https://gaap.ru/articles/kontrolling_v_torgovykh _kompaniyakh_v_strakhovykh_kompaniyakh_v _bankakh/

8. Losbichler H. Anforderungen a moderne Managementsystem // Controller Magazin 2012 Nr. 2. S.123-127. 40 Horvath P. Controlling. Muenchen: Vahlen Verlag, 2012. 